\title{
Effect of ciliates on nitrification and nitrifying bacteria in Baltic Sea sediments
}

\author{
Mario Prast ${ }^{1, *}$, Adrian A. Bischoff ${ }^{2}$, Uwe Waller ${ }^{2}$, Rudolf Amann ${ }^{3}$, \\ Ulrike-G. Berninger ${ }^{1}$ \\ ${ }^{1}$ University of Salzburg, Dept. of Organismal Biology, Hellbrunner Strasse 34, 5020 Salzburg, Austria \\ ${ }^{2}$ Leibniz Institute of Marine Sciences, IFM-GEOMAR, Düsternbrooker Weg 20, 24105 Kiel, Germany \\ ${ }^{3}$ Max Planck Institute for Marine Microbiology, Celsiusstrasse 1, 28359 Bremen, Germany
}

\begin{abstract}
Nitrification in aquatic sediments is catalyzed by bacteria. While many autecological studies on these bacteria have been published, few have regarded them as part of the benthic microbial food web. Ciliates are important as grazers on bacteria, but also for remineralization of organic matter. We tested the hypothesis that ciliates can affect nitrification. Experiments with Baltic Sea sediments in laboratory flumes, with or without the addition of cultured ciliates, were conducted. We found indication of a higher nitrification potential (ammonium oxidation) in one experiment and increased abundances of nitrifying bacteria in treatments with ciliates. This is likely due to higher nitrogen availability caused by excretion by ciliates and enhanced transport processes in the sediment.
\end{abstract}

KEY WORDS: Nitrifying bacteria $\cdot$ Ciliates $\cdot$ Nitrification $\cdot$ Bacteria $\cdot$ Sediment $\cdot$ FISH $\cdot$ Nitrification slurry assay

Resale or republication not permitted without written consent of the publisher

\section{INTRODUCTION}

The nitrogen cycle is one of the most important biogeochemical pathways, with nitrogen being an essential nutrient for all organisms. Various types of bacteria are responsible for many transformations within the nitrogen cycle. A large number of studies on these bacteria have been conducted in the past, but few investigators have looked at them as part of a food web, in which these bacteria have to compete with other organisms for nutrients/substrates and in which they might be prey for other components of the benthic food web (Verhagen \& Laanbroek 1992), particularly for ciliates (Lavrentyev et al. 1997, Strauss \& Dodds 1997). Our study focussed on nitrifying bacteria in sediments of the Baltic Sea and their possible trophic interactions with ciliates. Nitrification, the sequential oxidation of ammonium $\left(\mathrm{NH}_{4}{ }^{+}\right)$to nitrite $\left(\mathrm{NO}_{2}^{-}\right)$and then nitrate $\left(\mathrm{NO}_{3}^{-}\right)$, is predominantly accomplished by chemolithotrophic bacteria under oxic conditions. This process is a dominant biogeochemical pathway in the upper layer of aquatic sedi- ments, which are inhabited by large numbers and a high diversity of ciliates. Nitrifying bacteria consist of 2 functionally different groups of proteobacteria: ammonium-oxidizing bacteria (AOB) and nitriteoxidizing bacteria (NOB) (Spiek \& Bock 1998), as well as Archaea (Könnecke et al. 2005). The latter were only recently discovered and were not taken into consideration in this study, although they might be quantitatively important. Ciliates are important bacterial grazers in aquatic systems (Sherr \& Sherr 2002), including sediments (Epstein 1997, Cleven 2004), with a wide array of feeding strategies. Grazing pressure of protists can greatly affect bacterial activity and community structure (Šimek et al. 1997, Rønn et al. 2002, Matz \& Jürgens 2003). Hence, ciliate grazing is likely to affect the biogeochemical pathways in which bacteria play an essential role.

We designed a simple laboratory experiment using flumes filled with natural sediments, analyzing the effects of ciliates on the nitrification potential, the abundance and taxonomic composition of nitrifying bacteria in sediments. 


\section{MATERIALS AND METHODS}

Experimental setup. Experiments were conducted in 2 laboratory flumes (length: $32.44 \mathrm{~cm}$; width: $17.4 \mathrm{~cm}$; height: $18.7 \mathrm{~cm}$; depth of sediment layer: $\sim 7 \mathrm{~cm}$ ). The upper $20 \mathrm{~cm}$ of natural sediments were collected from the Baltic Sea (Bay of Kiel, intertidal zone, approximately $54^{\circ} 21^{\prime} \mathrm{N}, 10^{\circ} 09^{\prime} \mathrm{E}$ ), close to the shoreline, passed through a $2 \mathrm{~mm}$ sieve and incubated in the flumes for $40 \mathrm{~d}$ prior to the experiments in order to allow vertical gradients to re-establish. Water circulation was $\sim 10 \mathrm{l} \mathrm{h}^{-1}$ with artificial seawater (salinity: $26 \%$; temperature: $20^{\circ} \mathrm{C}$ ); each flume had an independent water circuit. Illumination was 12:12 h light:dark

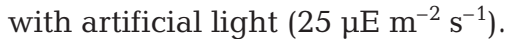

A ciliate cocktail consisting of several ciliate species initially isolated from the same sediments (for list of species see Table 3 ) and grown in the laboratory was added at a final density of $2.45 \times 10^{3}$ cells ml ${ }^{-1}$ of sediment to one of the flumes (+ ciliate treatment, + Cil). The ciliates were isolated $6 \mathrm{wk}$ prior to the experiments and were cultured in artificial seawater (salinity: $24 \%$ o) in the dark at $20^{\circ} \mathrm{C}$, with autoclaved wheat grains as the carbon source. No nitrifying bacteria were found among the food bacteria that developed in the cultures. An identical volume of $1.2 \mu \mathrm{m}$ filtered ciliate cocktail was added to the other flume as a control (-ciliate treatment, -Cil). Some ciliates in low natural abundances were still present in -Cil (see 'Results'). Water circulation was paused for $1.5 \mathrm{~h}$ after addition of the ciliates to allow them to settle and migrate into the sediments, followed by an incubation time of $3 \mathrm{~d}$.

Sampling procedure. All samples were taken with a plastic sediment corer (diameter: $16 \mathrm{~mm}$ ). Bacteria, flagellate and ciliate samples were transferred into preweighed $50 \mathrm{ml}$ plastic centrifugation tubes and fixed with glutardialdehyde $\left(\mathrm{GA}_{i} 2 \%\right.$ final concentration). Samples for nitrifying bacteria were also transferred into $50 \mathrm{ml}$ centrifugation tubes and were fixed with paraformaldehyde ( $4 \%$ final concentration). For each group 3 independent replicates per flume were collected. Samples for the determination of the nitrification potential were collected with the same type of corer, but transferred directly into the Erlenmeyer flasks used for the slurry assay (see below), with 6 independent replicates per flume. Samples for abiotic parameters such as sediment porosity, ash-free dry weight and grain size distribution were collected with a spoon and stored in $50 \mathrm{ml}$ centrifugation tubes until further processing ( 6 independent replicates per flume).

Enumeration of bacteria, flagellates and ciliates. Total bacterial and flagellate abundances were enumerated using epifluorescence microscopy. Fixed sam- ples were sonicated (Labsonic M, pulse: 0.9; amplitude: $60 \%$; 60 s) in order to separate attached bacteria from sediment particles and to break up bacterial aggregates. For extraction of bacteria and flagellates, samples were then resuspended in sterile artificial seawater with $2 \%$ GA and gently shaken by hand for $60 \mathrm{~s}$. Thereafter, $3.5 \mathrm{ml}$ of supernatant was immediately pipetted off into a $50 \mathrm{ml}$ centrifuge tube. To achieve a quantitative extraction, this washing procedure was repeated at least 5 times per sample. Then, 200 or $250 \mu \mathrm{l}$ of the supernatant was diluted with 1800 or $1750 \mu \mathrm{l}$ of particle-free artificial seawater, stained with DAPI (Porter \& Feig 1980) and filtered onto a black $0.2 \mu \mathrm{m}$ polycarbonate filter (Nuclepore) or a $0.8 \mu \mathrm{m}$ filter (Nuclepore) for bacterial and flagellate counts, respectively.

The NOB Nitrospira and Nitrobacter and the AOB Betaproteobacteria ( $\beta$-AOB) were detected with fluorescence in situ hybridization (FISH). Probes Ntspa712 and cNtspa712 (Daims et al. 2001) and NIT3 (Wagner et al. 1996) were used for NOB and Nso1225 (Mobarry et al. 1996) and for $\beta$-AOB, respectively (for details on these oligonucleotide probes see probeBase; Loy et al. 2003). All probes were labelled with the fluorescent dye Cy3. Hybridization procedures followed a protocol described previously by Pernthaler et al. (2001). Washing and filtration were identical to the procedures applied for the DAPI method, except that white $0.2 \mu \mathrm{m}$ filters (Nuclepore) were used.

Ciliate extraction followed the methods of Epstein (1995) and Cleven (2004). Samples were washed at least 7 times with $5 \mathrm{ml}$ of sterile artificial seawater amended with $2 \%$ GA to remove larger sand grains. After separation from the remaining sediment particles by density gradient centrifugation, ciliates were filtered onto $1.2 \mu \mathrm{m}$ cellulose nitrate filters (Sartorius), then counted and taxonomically identified using a silver-staining method that stains nuclei, cilia and ciliary basal bodies (Skibbe 1994). All counts were conducted using a Nikon Eclipse E800 microscope at 1000× magnification for bacteria and flagellates and $400 \times$ to $1000 \times$ for ciliates.

Nitrification potential (slurry assay). Sediment samples were slurried ( $6.5 \mathrm{~g}$ sediment $+100 \mathrm{ml}$ of $0.2 \mu \mathrm{m}$ filtered artificial seawater) and placed into $200 \mathrm{ml}$ Erlenmeyer flasks. Each flask was amended with $\mathrm{NH}_{4}{ }^{+}$ $(50 \mu \mathrm{M})$ and $\mathrm{NaClO}_{3}(20 \mathrm{mM})$ for $\mathrm{NH}_{4}{ }^{+}$oxidation rates or with $\mathrm{NO}_{2}^{-}(25 \mu \mathrm{M})$ and allylthiourea (ATU; $10 \mathrm{mg} \mathrm{l}^{-1}$ ) for $\mathrm{NO}_{2}^{-}$oxidation rates. $\mathrm{NaClO}_{3}$ and ATU are inhibitors for the respective complementary step of nitrification. Thus, in the treatment with $\mathrm{NaClO}_{3}$, the $\mathrm{NO}_{2}^{-}$ concentration increased, while it decreased in the treatment with ATU. The Erlenmeyer flasks were aerated and stirred continuously. Sub-samples were taken from each flask after $0,1.5,5$ and $22 \mathrm{~h}\left(t_{0}, t_{1}, t_{2}\right.$ and $t_{3}$, 
respectively). Prior to sampling, stirring and aeration were stopped for $5 \mathrm{~min}$. Samples were centrifuged for 5 min (Heraeus Labofuge 200, $2860 \times g$ ) to remove remaining sediment particles. $\mathrm{NO}_{2}^{-}$concentrations were measured photometrically using a Bran + Luebbe AutoAnalyzer (AA3, Method No. G-029-92 for nitriteN, Dollhopf et al. 2005, recommended by P. Stief pers. comm.). Nitrification potentials were calculated from the change in $\mathrm{NO}_{2}{ }^{-}$concentration over time.

Abiotic parameters. Temperature, $\mathrm{pH}$, oxygen saturation and salinity in the water circuit were measured with a multiprobe (WTW Multimeter 350i, ConOX and a SenTix 41 probes; Table 1), $\mathrm{NH}_{4}{ }^{+}, \mathrm{NO}_{2}{ }^{-}, \mathrm{NO}_{3}{ }^{-}$ and $\mathrm{PO}_{4}^{-}$concentrations were determined photometrically (Bran + Luebbe AutoAnalyzer AA3, Method No. G-029-92 for nitrite-N and G-016-91 for nitrateN). Dry weight, ash-free dry weight, porosity (calculated according to Hölting 1996) and grain size distribution were determined (Retsch AS 200 basic wet sieving machine; Table 2). All results given per gram refer to dry weight. SigmaXL (Version 2000) and SPSS (Version 11.0) software were used for statistical analyses.

In addition to the data shown, we tried to obtain in situ concentrations of $\mathrm{NH}_{4}{ }^{+}, \mathrm{NO}_{2}{ }^{-}$and $\mathrm{NO}_{3}{ }^{-}$with LIX microelectrodes (DeBeer et al. 1997); however, due to the salinity of the system this was not possible.

Table 1. Abiotic parameters in the different treatments in the experimental flumes. Data are means $\pm \mathrm{SD}(+\mathrm{Cil}:+$ ciliate treatment; -Cil: - ciliate treatment)

\begin{tabular}{|lcc|}
\hline & + Cil & - Cil \\
\hline pH & 8.6 & 8.5 \\
Water $\mathrm{O}_{2}$ saturation $(\%)$ & 87 & 92 \\
Temperature $\left({ }^{\circ} \mathrm{C}\right)$ & 20.3 & 20.9 \\
Salinity $(\%)$ & 26.2 & 25.8 \\
$\mathrm{NH}_{4}{ }^{+}(\mu \mathrm{M})$ & $47 \pm 14$ & $31 \pm 7$ \\
$\mathrm{NO}_{2}^{-}(\mu \mathrm{M})$ & $9 \pm 0.6$ & $6 \pm 0.8$ \\
$\mathrm{NO}_{3}{ }^{-}(\mu \mathrm{M})$ & $985 \pm 128$ & $828 \pm 107$ \\
$\mathrm{PO}_{4}^{-}(\mu \mathrm{M})$ & $186 \pm 0.6$ & $188 \pm 23$ \\
Sediment porosity & $32.8 \pm 1.1$ & $31.4 \pm 0.6$ \\
Sediment ignition loss $(\%)$ & $0.9 \pm 0.9$ & $1.7 \pm 2.1$ \\
\hline
\end{tabular}

Table 2. Sediment grain size distribution in the experimental flumes. Data are mean $\pm \mathrm{SD}$

\begin{tabular}{|cc|}
\hline Grain size $(\mathrm{mm})$ & Percent portion \\
\hline$>0.5$ & $32.2 \pm 3.7$ \\
$0.49-0.125$ & $63.1 \pm 3.4$ \\
$0.125-0.063$ & $1.1 \pm 0.6$ \\
$0.063-0.025$ & $0.3 \pm 0.3$ \\
$<0.025$ & $3.3 \pm 0.7$ \\
\hline
\end{tabular}

\section{RESULTS}

\section{Bacteria and flagellates}

In our sediment incubations, total bacterial abundances after the incubation period ranged from $5.4 \times$ $10^{8}$ to $6.0 \times 10^{9}$ cells g $^{-1}$ and numbers were similar in treatments with and without ciliates ( $t$-test, $\mathrm{p}=0.955$; Fig. 1). Abundances of the 3 investigated types of nitrifying bacteria (Nitrosomonas, Nitrospira and Nitrobacter) were always lower in the treatments without ciliates (Fig. 1). Together they contributed 1.45 and $0.35 \%$ of total bacteria in the treatments with and without ciliates, respectively. Although not statistically significant, the difference was most distinct for Nitrospira ( $t$-test, $\mathrm{p}=0.0585)$, followed by Nitrobacter ( $t$-test, $\mathrm{p}=$ 0.0702 ) and $\beta$-AOB ( $t$-test, $p=0.2613)$. Total flagellate abundance at the end of the incubation period was $2.5 \times 10^{5}\left( \pm 2.0 \times 10^{4}\right)$ cells $\mathrm{g}^{-1}$ in the + Cil treatment and $1.5 \times 10^{5}\left( \pm 3.8 \times 10^{4}\right)$ cells $\mathrm{g}^{-1}$ in the - Cil treatment; no significant difference between treatments was found. Total biovolumes of flagellates were similar in both

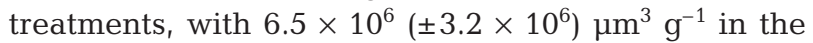

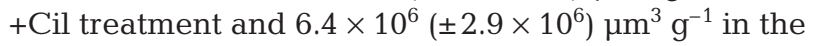
- Cil treatment. The proportion of autotrophic flagellates did not differ significantly between the treatments either, being 54 and $60 \%$ in terms of total flagellate abundance, but 84 and $91 \%$ of the total flagellate biovolume.

\section{Ciliates}

Ciliate abundance in +Cil was $1478( \pm 578)$ cells $^{-1}$, i.e. $52 \%$ of the ciliates initially added to the sediment were recovered. The abundance in -Cil was 189 $( \pm 120)$ cells $\mathrm{g}^{-1}$, which is significantly lower $(t$-test, $\mathrm{p}=$

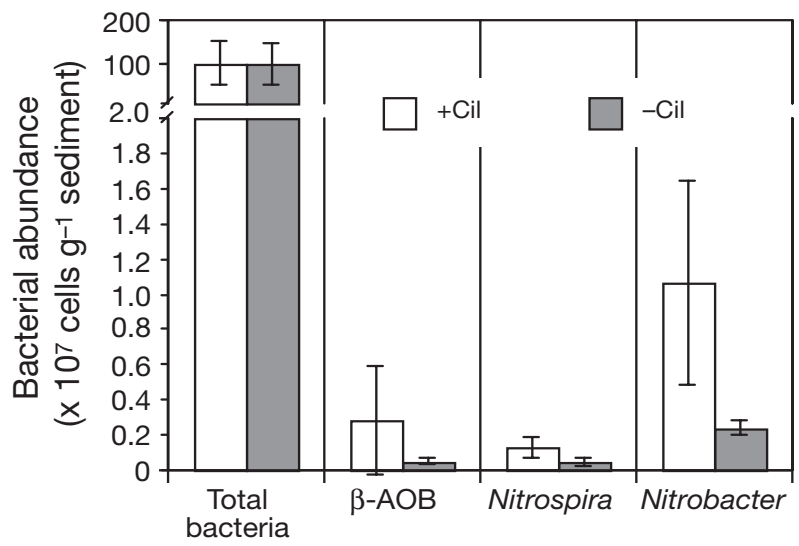

Fig. 1. Bacterial abundances in the experimental sediments after the incubation period (error bars $= \pm 1 \mathrm{SD}$ ). $\beta$-AOB: ammonium-oxidizing Betaproteobacteria. +Cil: + ciliate treatment; - Cil: - ciliate treatment 


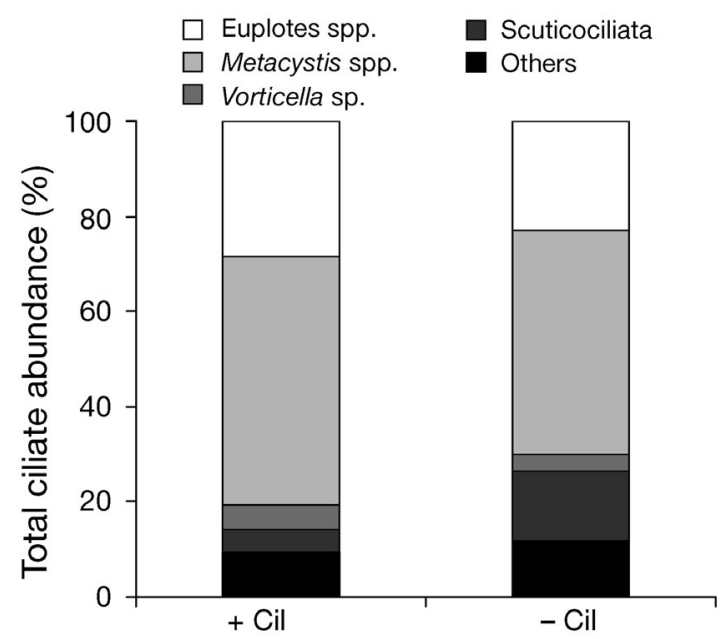

Fig. 2. Taxonomic composition of ciliates in the experimental flumes after the $3 \mathrm{~d}$ incubation period

0.006), reflecting the natural sediment abundance. The taxonomic composition of the ciliate community was very similar in both treatments $\left(\chi^{2}\right.$-test, $\mathrm{p}=0.999$; Fig. 2) and was dominated by Metacystis spp. and Euplotes spp. Together these 2 taxa contributed $80.5 \%$ (+Cil) and $70.0 \%(-\mathrm{Cil})$ to the total ciliate abundance. In addition, Aspidicsa sp., Coleps spp., Vorticella sp., Paramecium spp., Litonotus sp., Loxophyllum helus and various scuticociliates were found in lower abundances (Table 3).

\section{Nitrification potential}

Nitrification potentials ranging from 0.08 to $5.10 \mu \mathrm{g}$ $\mathrm{N} \mathrm{g}^{-1} \mathrm{~h}^{-1}$ were measured in the different treatments

Table 3. Taxonomic composition of the ciliate community ( $\%$ of total abundance). Total abundances were $1478( \pm 578)$ cells

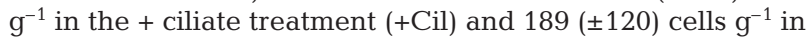
the - ciliate treatment $(-\mathrm{Cil})$. Data are mean $\pm \mathrm{SD}$

\begin{tabular}{|lcc|}
\hline Taxon & + Cil & - Cil \\
\hline Euplotes spp. & $28.5 \pm 11.8$ & $22.8 \pm 8.6$ \\
Aspidisca sp. & $1.0 \pm 1.6$ & $0.0 \pm 0.0$ \\
Metacystis spp. & $52.0 \pm 13.8$ & $47.2 \pm 21.0$ \\
Coleps spp. & $0.5 \pm 0.8$ & $2.2 \pm 3.8$ \\
Vorticella sp. & $5.4 \pm 1.0$ & $3.3 \pm 5.8$ \\
Paramecium spp. & $1.9 \pm 2.2$ & $3.3 \pm 5.8$ \\
Scuticociliata & $4.7 \pm 1.0$ & $14.7 \pm 20.0$ \\
Undeterminate Hymentomatida & $0.0 \pm 0.0$ & $2.1 \pm 3.6$ \\
Litonotus sp. & $0.5 \pm 0.8$ & $0.0 \pm 0.0$ \\
Loxophyllum helus & $1.6 \pm 2.7$ & $2.2 \pm 3.8$ \\
Undeterminate Pleurostomatida & $0.0 \pm 0.0$ & $2.1 \pm 3.6$ \\
Undeterminate ciliates & $4.0 \pm 3.1$ & $0.0 \pm 0.0$ \\
\hline
\end{tabular}

(Fig. 3). In -Cil, the rates were generally lower than in + Cil (except for nitrite oxidation $t_{1}$ to $t_{2}$ ). The difference was significant for ammonium oxidation $t_{1}$ to $t_{2}$ ( $t$ test, $\mathrm{p}=0.0294$ ), with rates for ammonium oxidation of $4.47( \pm 1.60), 0.61( \pm 0.17)$ and $0.35( \pm 0.08) \mu g \mathrm{~N} \mathrm{~g}^{-1} \mathrm{~h}^{-1}$ for $+\mathrm{Cil}$ and $3.37( \pm 1.48), 0.29( \pm 0.27)$ and $0.31( \pm 0.14)$ $\mu \mathrm{g} \mathrm{N} \mathrm{g}^{-1} \mathrm{~h}^{-1}$ for $-\mathrm{Cil}$ for $t_{0}$ to $t_{1}, t_{1}$ to $t_{2}$ and $t_{2}$ to $t_{3}$ respectively. Nitrite oxidation rates were $5.10( \pm 2.88)$, $0.08( \pm 0.08)$ and $0.25( \pm 0.09) \mu g \mathrm{~N} \mathrm{~g}^{-1} \mathrm{~h}^{-1}$ for $+\mathrm{Cil}$ and $2.54( \pm 0.99), 0.10( \pm 0.07)$ and $0.18( \pm 0.05) \mu g \mathrm{~N} \mathrm{~g}^{-1} \mathrm{~h}^{-1}$ for $-\mathrm{Cil}$. The high rates in the interval $t_{0}$ to $t_{1}$ caused a depletion of the substrates, and, consequently, the rates measured in the intervals $t_{1}$ to $t_{2}$ and $t_{2}$ to $t_{3}$ were much lower and not included in our further analysis.

\section{DISCUSSION}

Our experiments demonstrated that the increase in ciliate abundance could enhance the abundance of nitrifying bacteria and the nitrification potential in the sediments taken from the Baltic Sea. This was not always statistically significant, but reflected a distinct trend. A similar effect was found by Strauss \& Dodds

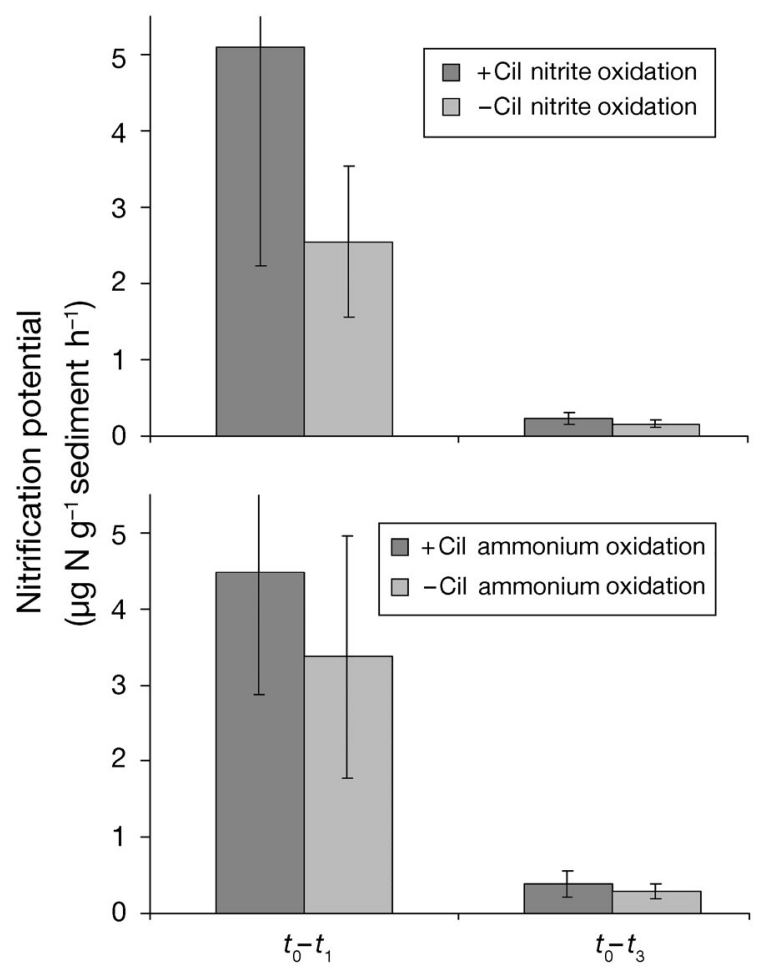

Fig. 3. Nitrification potentials of the sediments in the experimental flumes after the incubation period, as determined with slurry assays. Rates from $t_{0}$ to $t_{1}$ are shown. Due to the high rates, the substrates in the slurry assay were consumed very quickly and the rates from $t_{2}$ to $t_{3}$ were not used for further analysis $\left(t_{0}, t_{1}, t_{2}\right.$, and $t_{3}: 0,1.5,5$ and $22 \mathrm{~h}$, respectively; error bars: $\pm 1 \mathrm{SD}$ ) 
(1997) for submerged soil sediments. Although Lavrentyev et al. (1997) demonstrated that ciliates do ingest nitrifying bacteria, a recent study showed that selective grazing by a mixed ciliate community (ciliates preferring or discriminating against nitrifying bacteria; Neubacher et al. 2007) can be excluded. We conclude that the presence of ciliates, especially at high abundances, enhances transport processes in sediments (Glud \& Fenchel 1999) and thus improves substrate availability to nitrifying bacteria. Furthermore, ciliate digestion of food leads to an ammonium excretion of 0.25 to $2 \mu \mathrm{g} \mathrm{N} \mathrm{h}{ }^{-1} \mathrm{mg}^{-1}$ dry weight (Ferrier-Pagès \& Rassoulzadegan 1994), which further contributes to an increased substrate availability for nitrifiers in the presence of ciliates. Lavrentyev et al. (1997) showed that in planktonic systems ciliate grazing pressure can lead to the formation of large colonies of bacteria, making it more difficult for nitrifying bacteria to obtain substrates. This is unlikely to happen in an interstitial system, where most bacteria are attached to sediment particles (Kasimir 1990). Flagellate and total bacterial abundances after the incubation period did not differ between + Cil or -Cil, indicating that grazing pressure from ciliates was rather low or that grazing losses of bacteria and flagellates were compensated by increased growth, possibly accompanied by a change in community composition. As indicated by the large portion of biovolume, the flagellate community was dominated by large phototrophic flagellates; heterotrophic flagellates were rather small in size. Other studies have shown thatin contrast to planktonic systems - in sediments, ciliates might be more important as bacterial grazers than heterotrophic flagellates, and top-down control of benthic bacteria by heterotrophic flagellates seems unlikely (Dietrich \& Arndt 2000 and literature cited therein). Thus, flagellate grazing on bacteria was not considered as a factor interacting with the effect of ciliates on nitrification in our experimental system, but further studies might look at the role of flagellates more closely. In addition to bacteria and flagellates, diatoms were also found in our systems. Presumably they were too large as prey for the ciliate species in our sediments. As the ciliate abundance increased 8fold after the incubation period in +Cil, we assume that ciliate grazing pressure on bacteria and flagellates was rather high. This is consistent with the ciliate community composition being strongly dominated by small bacterivorous forms. Thus, the grazing pressure of ciliates increased the availability of nitrogen compounds, thereby allowing compensation of grazing losses due to higher growth rates of bacteria and flagellates. Our results further indicate that nitrifying bacteria profit disproportionately from higher substrate availability due to ciliate grazing, because ammonium as a substrate for nitrification is the main excretion product of ciliates (Ferrier-Pagès \& Rassoulzadegan 1994). Another explanation for the increase in nitrification potentials and the abundance of nitrifying bacteria in the treatments with high ciliate abundances might be an enhanced transport of solutes such as $\mathrm{NH}_{4}{ }^{+}, \mathrm{NO}_{2}{ }^{-}, \mathrm{NO}_{3}{ }^{-}$and $\mathrm{O}_{2}$ through the interstitial spaces due to the movement and filtration activity of the ciliates (Glud \& Fenchel 1999). Fenchel (1986) showed that ciliates can generate a significant flow, which may contribute to a better distribution of substrates in the interstitial spaces of the sediments, where transport is otherwise mostly limited to diffusion (Huettel \& Webster 2001).

Despite the significant difference of ciliate abundance between the treatments, a true control without any ciliates would have been desirable, but there is no practical method to completely remove ciliates selectively from sediments without damaging other components of the microbial community. Generating an artificial sediment system with sterile sand and bacteria, flagellates, ciliates, algae and metazoans from cultures does not seem to be a sufficient solution either, as such a system can hardly represent the complex interactions found in natural sediments. However, besides the rather high variability in the abundance of nitrifying bacteria in our samples, the presence of low numbers of ciliates in the control likely caused the lack of statistical significance in some of the effects of the experimental manipulation. In addition to the nitrification potentials, knowledge of in situ concentrations of nitrogen compounds and in situ nitrification rates would have been very useful. Such direct measurements would have avoided possible effects on the components of the microbial food web due to the use of inhibitors. However, because of the difficulties with the use of microsensors these data are not available. Furthermore, it cannot be completely ruled out that the use of other ciliate species might have attenuated or increased the effect on nitrifying bacteria. We are, however, confident that this is unlikely, since the ciliates used in our experiment represented the natural community very well. Here, $52 \%$ of the ciliates that were added initially were recovered after the incubation period. The remaining $48 \%$ probably did not find their way into the sediment and, consequently, were destroyed in the pump. As the measurements of $\mathrm{NH}_{4}{ }^{+}$, $\mathrm{NO}_{2}{ }^{-}, \mathrm{NO}_{3}{ }^{-}$and $\mathrm{PO}_{4}{ }^{-}$in the water column showed, this did not have a significant effect on the nutrient level and can be ruled out as a source of the increased nutrient supply in $+\mathrm{Cil}$.

Total bacterial abundances were well within the range of those reported for other marine and freshwater sediments (Llobet-Brossa et al. 1998, Kuwae \& Hosokawa 1999, Altmann et al. 2004). In some studies, 
bacteria of the genus Nitrospira have been identified as the dominating NOB in marine and freshwater systems (Hovanec et al. 1998, Altmann et al. 2003). In our study, bacteria of the genus Nitrobacter were the quantitatively most important NOB. Abundances of Nitrobacter exceeded Nitrospira abundances $>5$-fold in -Cil and 8-fold in +Cil. In both treatments, Nitrobacter accounted for $71 \%$ of the detected nitrifying bacteria. Other NOB, such as Nitrospina or Nitrococcus, might have also been present, but are unlikely to be numerically important (Watson et al. 1981). During the course of our experiments, a new ammoniaoxidizing Crenarchaeota was described (Könneke et al. 2005). Future experiments should consider the presence and abundance of this new type of ammoniaoxidizing microorganism, which might show a different reaction to ciliate grazing.

\section{CONCLUSIONS}

Ciliates affect the abundance of nitrifying bacteria in sediments and, hence, the nitrification potential. The likely reason for the increased abundances of nitrifiers and nitrification potentials in the presence of ciliates is probably nitrogen recycling, which leads to enhanced nitrogen availability for nitrifying bacteria. This indicates that nitrifying bacteria are subject to bottom-up control by substrate availability rather than top-down control through ciliate grazing. Ciliate grazing did not negatively affect the nitrifying bacteria quantitatively, although Lavrentyev et al. (1997) and Neubacher et al. (2007) showed that they are ingested by ciliates. Another possible explanation for the increased abundances of nitrifying bacteria and nitrification potentials in + Cil might be an increased transport of substrates and oxygen in the sediments due to the movement and filtration activities of the ciliates.

Although the results of the present study lead to the conclusion that ciliates should be considered as a controlling factor for nitrifying bacteria and nitrification, further studies on this relationship are necessary. These should focus on a comparison with other marine and freshwater systems; in situ experiments should be conducted, and seasonal effects should be taken into account.

Acknowledgements. We are grateful to the German Environmental Foundation (Deutsche Bundesstiftung Umwelt) for their financial support (AZ20002/266). We thank P. Stief, M. Claeßens-Kenning, S. Agatha, E. J. Cleven, E. Neubacher and 3 anonymous reviewers for helpful suggestions, the German Institute of Hydrology (Bundesanstalt für Gewässerkunde) for technical support, S. A. Wickham for advice on statistical analysis and S. Mees, A. Pitt and C. Lorenz for support with the practical work.

\section{LITERATURE CITED}

Altmann D, Stief P, Amann R, DeBeer D, Schramm A (2003) In situ distribution and activity of nitrifying bacteria in freshwater sediment. Environ Microbiol 5:798-803

Altmann D, Stief P, Amann R, DeBeer D (2004) Distribution and activity of nitrifying bacteria in natural stream sediment versus laboratory sediment microcosms. Aquat Microb Ecol 36:73-81

Cleven EJ (2004) Seasonal and spatial distribution of ciliates in the sandy hyporheic zone of a lowland stream. Eur J Protistol 40:71-84

Daims H, Nielsen JL, Nielsen PH, Schleifer KH, Wagner M (2001) In situ characterization of Nitrospira-like nitriteoxidizing bacteria active in wastewater treatment plants. Appl Environ Microbiol 67:5273-5284

DeBeer D, Schramm A, Santegoeds CM, Kühl M (1997) A nitrite microsensor for profiling environmental biofilms. Appl Environ Microbiol 63:973-977

Dietrich D, Arndt H (2000) Biomass partitioning of benthic microbes in a Baltic inlet: relationships between bacteria, algae, heterotrophic flagellates and ciliates. Mar Biol 136: 309-322

Dollhopf SL, Hyen JH, Smith AC, Adams HJ, O'Brien S, Kostka JE (2005) Quantification of ammonia-oxidizing bacteria and factors controlling nitrification in salt marsh sediments. Appl Environ Microbiol 71:240-246

Epstein SS (1995) Simultaneous enumeration of protozoa and micrometazoa from marine sandy sediments. Aquat Microb Ecol 9:219-227

Epstein SS (1997) Microbial food webs in marine sediments. II. Seasonal changes in trophic interactions in a sandy tidal flat community. Microb Ecol 34:199-209

Fenchel T (1986) Protistan filter feeding. Prog Protistol 1: 65-113

Ferrier-Pagès C, Rassoulzadegan F (1994) N remineralization in planktinic protozoa. Limnol Oceanogr 39:411-419

Glud RN, Fenchel T (1999) The importance of ciliates for interstitial solute transport in benthic communities. Mar Ecol Prog Ser 186:87-93

Hölting B (1996) Hydrogeologie. Enke-Verlag, Stuttgart

Hovanec TA, Taylor LT, Blakis A, Delong EF (1998) Nitrospira-like bacteria associated with nitrite oxidation in freshwater aquaria. Appl Environ Microbiol 64:258-264

Huettel M, Webster IT (2001) Porewater flow in permeable sediments. In: Boudreau BP, Jørgensen BB (eds) The benthic boundary layer: transport processes and biogeochemistry. Oxford University Press, New York, p 144-179

Kasimir GD (1990) Mikrobiologische Untersuchungen im Lunzer Seebach (Ritrodat). Jahresber Biol Stn Lunz 12: $55-69$

Könneke M, Bernhard AE, de la Torre JR, Walker CB, Waterbury JB (2005) Isolation of an autotrophic ammonia-oxidizing marine archaeon. Nature 437:543-546

Kuwae T, Hosokawa Y (1999) Determination of abundance and biovolume of bacteria in sediments by dual staining with 4',6-diamidino-2-phenylindole and acridine orange: relationship to dispersion treatment and sediment characteristics. Appl Environ Microbiol 65:3407-3412

Lavrentyev PJ, Gardner WS, Johnson JR (1997) Cascading trophic effects on aquatic nitrification: experimental evidence and potential implications. Aquat Microb Ecol 13:161-175

Llobet-Brossa E, Rosselló-Mora R, Amann R (1998) Microbial community composition of Wadden Sea sediments as revealed by fluorescence in situ hybridization. Appl Environ Microbiol 64:2691-2696 
Loy A, Horn M, Wagner M (2003) probeBase-an online resource for rRNA-targeted oligonucleotide probes. Nucleic Acids Res 31:514-516

Matz C, Jürgens K (2003) Interaction of nutrient limitation and protozoan grazing determines the phenotypic structure of a bacterial community. Microb Ecol 45:384-398

Mobarry BK, Wagner M, Urbain V, Rittmann BE, Stahl DA (1996) Phylogenetic probes for analyzing abundance and spatial organization of nitrifying bacteria. Appl Environ Microbiol 62:2156-2162

Neubacher E, Prast M, Cleven EJ, Berninger UG (2007) Do ciliates have an effect on the nitrogen cycle through grazing on nitrifying bacteria? Hydrobiologia (in press)

Pernthaler J, Glöckner FO, Schönhuber W, Amann R (2001) Fluorescence in situ hybridization (FISH) with rRNAtargeted oligonucleotide probes. In: Paul H (ed) Methods in microbiology, Vol 30. Academic Press, San Diego, CA, p 207-226

Porter KG, Feig YS (1980) The use of DAPI for identifying and counting aquatic microflora. Limnol Oceanogr 25: 943-948

Rønn R, McCaig AE, Griffiths BS, Prosser JI (2002) Impact of protozoan grazing on bacterial community structure in soil microcosms. Appl Environ Microbiol 68:6094-6105

Sherr EB, Sherr BF (2002) Significance of predation by protists in aquatic microbial food webs. Antonie Leeuwen-

Editorial responsibility: Otto Kinne (Editor-in-Chief), Oldendorf/Luhe, Germany hoek 81:293-308

Šimek K, Vrba J, Pernthaler J, Posch T, Hartman P, Nedoma J, Psenner R (1997) Morphological and compositional shifts in an experimental bacterial community influenced by protists with contrasting feeding modes. Appl Environ Microbiol 63:587-595

Skibbe O (1994) An improved quantitative protargol stain for ciliates and other planktonic protists. Arch Hydrobiol 130: 339-347

Spiek E, Bock E (1998) Taxonomische, physiologische und ökologische Vielfalt nitrifizierender Bakterien. Biospektrum 4:25-31

Strauss EA, Dodds WK (1997) Influence of protozoa and nutrient availability on nitrification rates in subsurface sediments. Microb Ecol 34:155-165

Verhagen FJM, Laanbroek HJ (1992) Effects of grazing by flagellates on competition for ammonium between nitrifying and heterotrophic bacteria in chemostats. Appl Environ Microbiol 58:1962-1969

Wagner M, Rath G, Koops HP, Flood J, Amann R (1996) In situ analysis of nitrifying bacteria in sewage treatment plants. Water Sci Technol 34:237-244

Watson SW, Valois FW, Waterbury JB (1981) The family Nitrobacteraceae. In: Starr MP, Stolp $\mathrm{H}$, Trüper $\mathrm{HG}_{\text {, }}$ Balows A, Schlegel HG (eds) The prokaryotes. SpringerVerlag, Berlin, p 1005-1022

Submitted: October 27, 2006; Accepted: July 4, 2007 Proofs received from author(s): November 11, 2007 